\title{
The influence of cultivar and enzyme treatment on the aroma complex of apple juice
}

\author{
Asima AKAGIĆ ${ }^{1 \star}$ (D), Nermina SPAHO ${ }^{1}$, Sanja ORUČEVIĆ ŽULJEVIĆ ${ }^{1}$
}

\begin{abstract}
This paper aims to determine the influence of a cultivar (Golden delicious and Granny Smith) and enzyme treatments (hot and cold) on the aroma complex of clear apple juice. While the composition of aromatic components of the juice was determined by Gas Chromatography Mass Spectrometry (GC/MS) technique, a panel of 24 semi trained evaluators carried out sensory analysis. There are certain differences in the identified aromatic compounds of juice produced of these two apple cultivars. The most abundant aromatic compounds of apple juice were esters and aliphatic alcohols. Juice made from Granny Smith are determinated with higher content of 2-methylbutyl acetate (isoamyl acetate), hexyl acetate, hexyl butanoate, butyl butanoate, butyl acetate, pentyl acetate and butyl propanoate. It is possible to connect enzymatic treatments with some of the esters. Three esters such as1-(1.1-Dimethylethyl)-2-methyl-1.3-propanediyl 2-methylpropanoate, methyl dihydrojasmonate and ethyl butanoate are specific for the hot enzyme treatment. Cold depectinization processes could be recommended for the juice industry because this treatment better protects aromatic compounds. The panellist preferred apple juice of Granny Smith with flavours which stand for the typical aroma of ripe apples.
\end{abstract}

Keywords: clear juice; depectinization; aroma compounds; sensory attributes.

Practical Application: Cold enzyme treatment protecting secondary plant metabolites in juice.

\section{Introduction}

Apple is a very suitable raw material for juice production due to its good yields, high dry matter content, relatively low cost and the possibility of using secondary products thereof in the range of highly valuable products. For the production of apple juice, it is particularly important to select appropriate cultivar (Carbone et al., 2011; Mehrabani et al., 2011; Liaudanskas et al., 2014; Begić-Akagić et al., 2014; Akagić et al., 2019) because of the specific sensory properties and biochemical processes that occur during technological processes (Begić-Akagić et al., 2011).

Apple flavour is a complex mixture of apple taste and aromatic compounds. The aroma profile of apple fruit consists of over 300 different aromatic compounds, including esters, alcohols, aldehydes, ketones, terpenes and ethers (Paillard, 1990). Thus, numerous biosynthetic pathways are responsible for flavour production in apple. Volatile compounds important for aroma and flavour are synthesised from fatty acids, amino acids and carbohydrates (Rowan et al., 1999). In apple aroma, the majority of volatile compounds are esters, $78-98 \%$ of total volatiles and alcohols, $6-16 \%$ of total volatiles (Hey et al., 2007; Cheetham, 2010). Aroma esters are believed to be synthesized enzymatically from alcohols and acyl CoA via alcohol acetyltransferase (AAT). AAT catalyzes the transfer of an acyl moiety from acyl-CoA onto the corresponding alcohol to form an ester (Fellman \& Mattheis, 1995). About 20 of volatile compounds are really crucial to characterize the apples aroma such as, acetaldehyde, ethyl acetate, ethyl butanoate, ethyl methyl propanoate, 2-methyl butanol, 2-methyl butyl acetate, butyl acetate, hexyl acetate, ethyl butyrate, methyl anthranilate, and ethyl 2-methyl butyrate, hexyl butanoate, hexyl hexanoate, (E)-2-hexenal, (Z)-2-hexenal (Holland et al., 2005; Ferreira et al., 2009; Gonçalves et al., 2018).

There is a large number of factors that could affect the composition of the apple juice aroma complex such as cultivation (Roth et al., 2007), the cultivar (Young et al., 2004; Fraternale et al., 2011), post-harvest handling, processing, packing and storing (Beaulieu \& Baldwin, 2002; Argenta et al., 2004; Kevers et al., 2011; Altisent et al., 2011). In the apple juice production, exposure to high temperatures, either during the enzyme treatment (hot or cold) or during pasteurization and sterilization causes a change in the primary flavours and aroma, resulting in the formation of the aroma secondary products of which is almost completely different from the aroma of fresh apples (Lea, 1999; Sharma et al., 2015). On the other hand, the assessment of apple juice quality based solely on chemical analysis is not possible. Sensory evaluation plays an integral part not to be omitted in the quality assessment of apple juice and by no means can be replaced by an assessment solely based on analytical data (Quadt et al., 2008). To the best of our knowledge no data exist regarding the aroma complex of apple juice influenced by cultivar and enzyme treatment. Based on the facts that apple cultivars such as Granny Smith and Golden Delicious are widely spread in Bosnia and Herzegovina and provide appropriate chemical and sensory properties they were selected for investigation in this paper.

Therefore, the aim of this paper is to scan (i) the aromatic compounds in relation to enzyme treatment and cultivar, and (ii) the impact of the cultivar and enzyme treatment on the 
sensory properties of apple juice. The aroma complex of the juice was determined by GC/MS instrumental technique, and semi trained evaluators carried out evaluation of sensory properties.

\section{Materials and methods}

\subsection{Plant material}

Apple cultivars Granny Smith (GS) and Golden Delicious (GD) were picked at optimal harvest time in Gradačac orchard in Bosnia and Herzegovina. The fruits were stored in normal atmosphere at $1{ }^{\circ} \mathrm{C}$ and $90 \%$ of relative humidity for about three months until used in the experiments. The results of physical and chemical analyses of apple cultivars are shown in the Table 1.

\subsection{Preparation of clear apple juice}

Apple juice samples are produced of two apple cultivars Granny Smith $(60 \mathrm{~kg})$ and Golden Delicious $(60 \mathrm{~kg})$ as well as hot and cold enzyme treatments by standard procedure (Lea, 1999). All experiment was carried out in three replications. Apples were washed with cold water to remove surface dirt and microbial flora. The degradation of starch is controlled with the iodine test. The apples were crushed in laboratory apple grinder equipment. After crushing, the mixture was pressed in a manual laboratory press. To eliminate large particles, extracted juice was filtered through six layers of cheese cloth. After filtration, the row juice was divided into two lots (A, B). Granulated enzyme preparations (Lallzyme HC, France) have to be diluted in cold tap water (1:10) before they are added to the juice in lot $\mathrm{A}$. The raw apple juice was hot enzyme treated $(\mathrm{H})$ with $5 \mathrm{mg} / \mathrm{L}$ pectolytic enzyme at $50{ }^{\circ} \mathrm{C}$ for $2 \mathrm{~h}$ till pectin degradation. Pectin degradation was tested by alcohol test. After that the samples were sequentially flocculated with $550 \mathrm{mg} / \mathrm{L}$ of gelatine (DGF Stoess AG, tip A) and $1800 \mathrm{mg} / \mathrm{L}$ bentonite (Erde typ 2, Italy). The clear juice was obtained by filtration through kieselguhr. The juices were filled into hot glass bottles, and pasteurised at $80^{\circ} \mathrm{C} 10 \mathrm{~min}$. The raw apple juice in lot B was cold enzyme treated (C) with $5 \mathrm{mg} / \mathrm{L}$ of pectolytic enzyme preparation at $20^{\circ} \mathrm{C}$ for $8 \mathrm{~h}$. until the degradation of pectin. After the enzyme treatment, the process was the same as earlier described in lot A (Brotlija et al., 2010).

\subsection{Extraction and GC/MS analysis of aroma complex}

The isolation of headspace volatiles was performed in duplicate for each juice sample using manual SPME fibre with

Table 1. The physical and chemical characteristics of apple cultivars.

\begin{tabular}{lcc}
\hline \multirow{2}{*}{$\begin{array}{c}\text { The physical-chemical } \\
\text { characteristics }\end{array}$} & \multicolumn{2}{c}{ Cultivar } \\
\cline { 2 - 3 } & Granny Smith & Golden Delicious \\
\hline Total acidity $(\mathrm{g} / \mathrm{kg})$ & $3.69 \pm 0.27$ & $0.89 \pm 0.16$ \\
Total dry matter $(\mathrm{g} / 100 \mathrm{~g})$ & $14.25 \pm 0.8$ & $16.66 \pm 1.240$ \\
Reducing sugar $(\mathrm{g} / 100 \mathrm{~g})$ & $7.84 \pm 0.061$ & $11.62 \pm 0.139$ \\
L-ascorbic acid $(\mathrm{mg} / 100 \mathrm{~g})$ & $0.68 \pm 0.141$ & $0.39 \pm 0.134$ \\
Total phenols $(\mathrm{g} \mathrm{GAE} / \mathrm{kg})$ & $0.722 \pm 0.044$ & $0.612 \pm 0.033$ \\
Pectin content $(\mathrm{g} / 100 \mathrm{~g})$ & $0.557 \pm 0.025$ & $0.691 \pm 0.038$ \\
\hline
\end{tabular}

the layer of divinylbenzen/carboxene/polydimethylsiloxane (DVB/CAR/PDMS) obtained from Supelco Co. (Bellefonte, PA, USA). The fibre was conditioned prior to use according to the manufacturer instructions by inserting into the GC injector port. For each HS-SPME extraction, $8 \mathrm{~mL}$ of apple juice were used. The ionic strength was increased using $\mathrm{NaCl}$-sat. Juice with salt (7 mL) was placed in a $15-\mathrm{ml}$ amber glass vial and hermetically sealed with PTFE/silicone septa. The vial was maintained in a water bath at $60^{\circ} \mathrm{C}$ during equilibration $(15 \mathrm{~min})$ and extraction (40 $\mathrm{min}$ ), and it was partially submerged so that the liquid phase of the sample was in the water (modified by Steffen \& Pawliszyn, 1996).

For gas chromatography was used GC 7890A Agilent Technologies (Paolo Alto, CA, USA) in combination with spectrometer MS 5975C Agilent Technologies (Paolo Alto, CA, USA). The analysis was made using a GC capillary column HP-5MS (5\%-phenyl, methylpolysiloxane and a film thickness of $0.25 \mu \mathrm{m}$, the mobile phase and helium as the carrier gas (flow rate $1.0 \mathrm{~mL} \mathrm{~min}^{-1}$ ), the length of column is 30 and $0.25 \mathrm{~mm}$ in diameter. The oven ramp was programmed to run for 2 minutes at an initial temperature of $70{ }^{\circ} \mathrm{C}$, which was then increased for $4{ }^{\circ} \mathrm{C}$ per minute until it reached $200{ }^{\circ} \mathrm{C}$. Solvent delay was $4.50 \mathrm{~min}$, detector temperature $280^{\circ} \mathrm{C}$, injector temperature $250^{\circ} \mathrm{C}$ and injection volume was $1 \mu \mathrm{L}$. In this method, the MS acquisition parameters were: EI ionization of $70 \mathrm{eV}$, ion source temperature of $280{ }^{\circ} \mathrm{C}$ and interval of mass spectrometer recording of 30-300 mass units. Individual peaks were identified by comparing their retention indices (relative to $\mathrm{C}_{8}-\mathrm{C}_{30} n$-alkanes for HP-5MS column) against those from the literature, as well as by comparing their mass spectra with Wiley 275 MS library and NIST98 (National Institute of Standards and Technology) database. The percentages of identified components in samples of apple juice were calculated from GC peak areas.

\subsection{Sensory analysis}

Sensory analysis was conducted after the production of clear apple juices. An average sample was made from the three repetitions of all produced juice variants and prior to sensory evaluation the samples were refrigerated. The samples were presented using Latin Square order as a $20 \mathrm{~mL}$ juice in clear glass cup with 3-digit code number at $15{ }^{\circ} \mathrm{C}$. For the cleansing the palate the still water and unsalted crackers were used. In sensory analysis applied were a scoring method and a unified grading scale. The evaluation was carried out by 24 semi trained evaluators who passed a screening test according to recommendations given in ISO 8586. They evaluated the following sensory attributes: taste, aroma, freshness, stability and the secondary impression. Each attribute was rated on the 5-point scale (1 -dissatisfactory, 5 - excellent according to Perez-Cacho et al., 2008).

\subsection{Statistical analysis}

The results of sensory evaluation were analysed through descriptive statistics while the mean of all variants were analysed through ANOVA to establish statistically significant impact of tested factors (cultivar and enzyme treatment) on sensory properties, using the SPSS 16 program. Principal component analysis (PCA), using STAT box software (version 6.7, GRIMMER 
SOFT, France) has been used to discriminate between enzyme treatments and cultivars in relation to volatile compounds.

\section{Results and discussion}

In this part of the paper the results of aroma complex instrumental analysis are presented, as well as sensory profile of Granny Smith and Golden Delicious apple juice made through hot and cold enzyme treatment. Fifty-nine aromatic compounds were identified in analysed apple juices and included 17 esters, 12 aliphatic alcohols, 8 terpenes, 7 acids, 5 aldehydes, 3 ketones and 7 other compounds (Table 2). A common feature of all apple juices obtained is the predominance of esters and aliphatic alcohols. It is in accordance with composition of other fruit juice: apricot, peach and pear (Riu-Aumatell et al., 2004). As it can be seen in Table 2 the most abundant esters are butanoate (7 esters) and acetic ester types (5 esters), propanoate ( 2 esters) and then decanoate, dodecanoate and jasmonate.

More compounds were found in the analysed apple juice samples than in other studies for fresh and processed apple (Komthong et al., 2007; Nikfardjam \& Maier, 2011; Schmutzer et al., 2014; Espino-Díaz et al., 2016). This may be due to the different fruit properties (cultivars, ripening stage, growing conditions, origin), and to the distinct treatments used for juice extraction (depectinization - hot and cold). Different methods for aroma analysis give various results, too. There are certain differences in the identified aromatic compounds of these two apple cultivars (Table 2). This corresponds to earlier claims that there are large differences in terms of aroma and flavour of different cultivars (López et al., 1998; Mehinagic et al., 2004; Thielen et al., 2006; Fraternale et al., 2011; Iaccarino et al., 2019). Juices produced from both apple cultivars by hot enzyme treatment show a decrease in aromatic components in relation to cold ones: the Granny Smith cultivar under a hot enzyme treatment shows a decrease of $9.18 \%$ and Golden Delicious of $8.80 \%$. According to Gasperi et al. (2009) treatments of apple juice such as $\mathrm{CO}_{2}$ pasteurisation and $\mathrm{N}_{2} \mathrm{O}$ reduce the concentrations of many aromatic compounds: overall depletions of $35 \%$ for carbon dioxide and $26 \%$ for nitrous oxide were observed. The dataset (total amount of all chemical group $\mathrm{x}$ juice samples) was submitted to PCA (Figure 1). PCA was implemented in order to obtain an overview of the samples' classification pattern in relation to the total amount of all investigated aromatic compounds. PCA model with two components was computed on the total set of samples and explained sufficiently the $93 \%$ of the dataset variance as displayed in Figure 1. It is clear that juice samples are divided in two clusters based on the enzyme treatments while apple cultivar didn't show any base for distinguishing total aroma compounds in juices. Juices obtained by hot enzyme treatment are determinate by higher total amount of aliphatic alcohols and aldehydes and especially with much higher total amount of ketones and terpenes than the juices obtained by cold enzyme treatment.

Higher content of aldehydes in the juice samples obtained with hot enzyme treatments was probably affected by increasing fatty acids oxidation due to higher temperature applied. Also, the increase in aldehydes occurs due to Strecker's degradation during heating of the matrix (Weenen \& van der Ven, 2001). The content of esters reduces during hot enzyme treatment in relation to cold ones (HGS -2.8\% and CGS-34.6\% -Table 2) because the esters break down due to elevated temperature. Azhu Valappil et al. (2009) found that thermally treated apple cider lost $30 \%$ of their original ester and aldehyde contents during storage. In contrast to the hot enzyme treatments, cold enzyme treatments is classified with higher amount of total esters, acids and other investigated aroma compounds (1-methoxy-4-methylbenzene ( $p$-methylanisole), 2-phenylethanol, methyl chavicol (estragole), 4 -vinylphenol, chavicol). Aroma of apple juice is strongly correlated with trans-2-hexenal, hexanol and butanol, and it is in the negative correlation with ethanol and ethyl acetate (Lea, 1999). On the other hand, Hey et al. (2008) reported that sole parameters cannot be used for the determination of apple juice quality because the manifold apple varieties and technological steps lead to a variation in single aroma compounds and their particular relations. The steps such as pasteurization can produce undesirable quality changes such as loss of colour and flavour in addition to reducing the nutritional quality of juice (Vikram et al., 2005).

As the most dominant compounds in juices the group of esters and higher alcohols will be discussed in more detail. In order to determine the differentiation between apple cultivar and enzyme treatments in ratio to esters content principal component analysis was performed. An overview of the similarities and differences amongst the four juice samples on the basis of apple cultivar (Golden Delicious while Granny Smith) and enzyme treatment used (cold and hot) was shown in Figure 2. Distributions of juice samples are determined by the content of individual esters, shows segregation in accordance with applied enzyme treatments as well apple cultivar. Figure 2a better displays samples differentiation based on applied enzyme treatments while Figure $2 b$ shows better distinguish juice samples in relation to apple cultivars. As it can be seen in Figure 2a, the majority of esters are located on the above part of plot where the juices with cold enzyme treatment are located.

According to Ferreira et al. (2009) and Gonçalves et al. (2018) compounds such as ethyl acetate, ethyl butyrate and methyl anthranilate are really crucial to characterize the apples aroma, means that cold treatment gives better yield in ester content in compare to hot enzyme treatment. Also, it can be seen that are some differences between apple cultivar used in cold treatment. Juices made from Golden Delicious in cold enzyme treatment stand out by ethyl acetate, methyl butanoate, methyl 2-methylbutanoate, ethyl 2-methylbutanoate, ethyl decanoate, ethyl dodecanoate and propyl butanoate. On the other hand, juice made from Granny Smith are determinated with higher content of 2-methylbutyl acetate (isoamyl acetate), hexyl acetate, hexyl butanoate, butyl butanoate, butyl acetate, pentyl acetate and butyl propanoate. According to Wolter et al. (2010) quantitatively dominant esters in apple are 2-methylbutyl acetate and hexyl acetate, which, because of their comparison to ethyl 2-methyl butyrate and ethyl butyrate higher odour threshold values, make a comparatively low qualitative contribution to the apple-juice aroma. The remaining three esters: 1-(1,1-dimethylethyl)-2-methyl-1,3-propanediyl2methylpropanoate, methyl dihydro- jasmonate and ethyl butanoate are presented on Figure 2b. Those three esters are 
Table 2. Volatile headspace compounds of clear juice of apple cultivars Granny Smith and Golden Delicious obtained by hot and cold enzyme treatments.

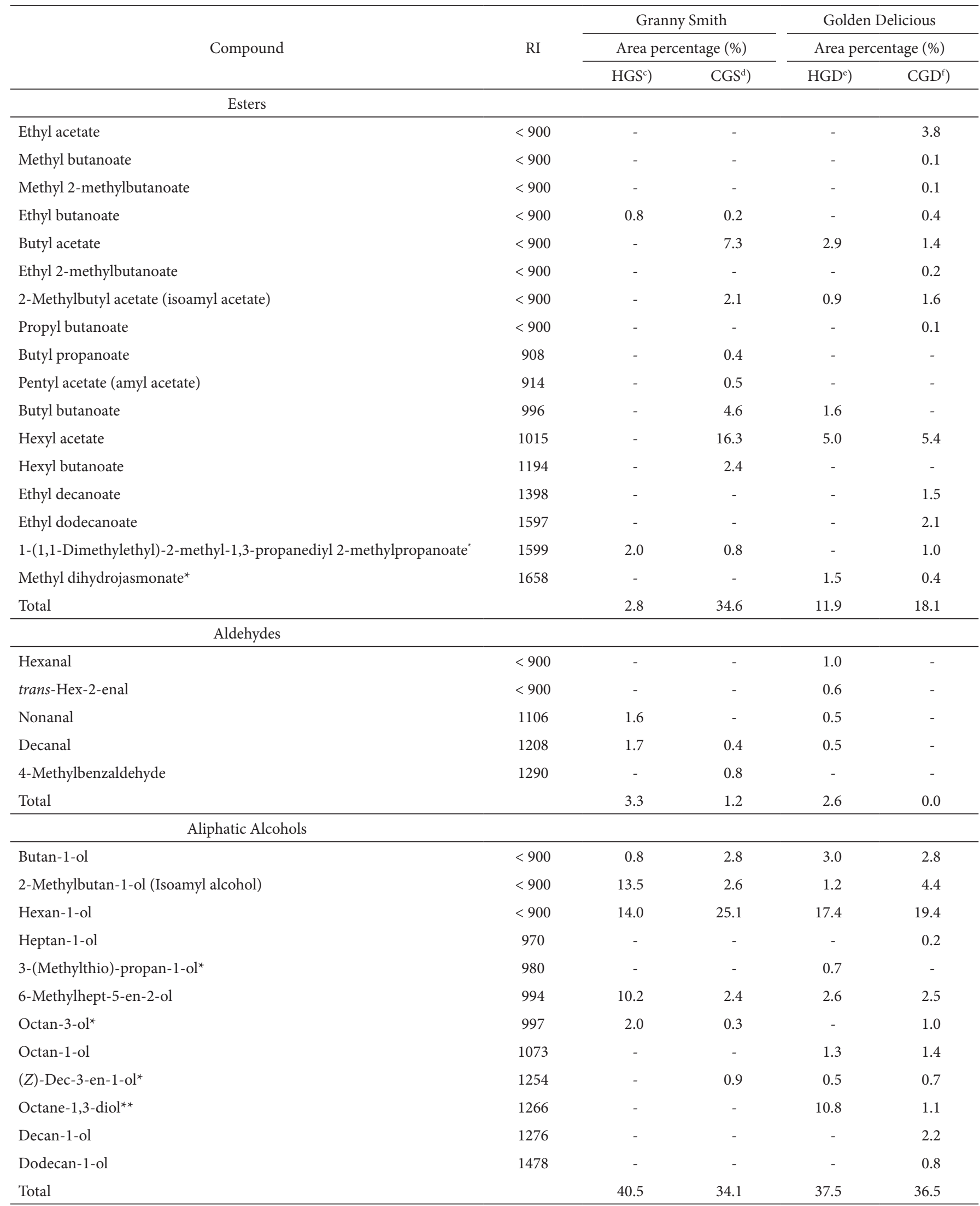

RI-retention indices on HP-5MS column. ${ }^{*}$ - compound tentatively identified. ${ }^{\text {a }}$ GS $=$ Granny Smith cultivar. ${ }^{b}$ ) GD $=$ Golden Delicious. ${ }^{c}$ ) HGS $=$ hot enzyme treatment of Granny Smith cultivar. ${ }^{d}$ ) CGS = cold enzyme treatment of Granny Smith cultivar. ${ }^{\mathrm{e}}$ ) HGD = hot enzyme treatment of Golden Delicious. ${ }^{\text {f }}$ CGD = cold enzyme treatment of Golden Delicious. 
Table 2. Continued...

\begin{tabular}{|c|c|c|c|c|c|}
\hline \multirow{3}{*}{ Compound } & \multirow{3}{*}{ RI } & \multirow{2}{*}{\multicolumn{2}{|c|}{$\begin{array}{c}\text { Granny Smith } \\
\text { Area percentage (\%) }\end{array}$}} & \multirow{2}{*}{\multicolumn{2}{|c|}{$\begin{array}{c}\text { Golden Delicious } \\
\text { Area percentage (\%) }\end{array}$}} \\
\hline & & & & & \\
\hline & & $\left.\mathrm{HGS}^{c}\right)$ & $\left.\mathrm{CGS}^{\mathrm{d}}\right)$ & $\left.\mathrm{HGD}^{\mathrm{e}}\right)$ & $\left.\mathrm{CGD}^{\mathrm{f}}\right)$ \\
\hline \multicolumn{6}{|l|}{ Ketones } \\
\hline Nonan-2-one & 1094 & 1.0 & - & - & - \\
\hline trans- $\beta$-Damascenone & 1387 & 6.9 & 0.6 & 7.5 & 2.6 \\
\hline 2-Hydroxy-5-isopropyl-4-methyl - acetophenone & 1426 & - & - & 2.6 & - \\
\hline Total & & 7.9 & 0.6 & 10.1 & 2.6 \\
\hline \multicolumn{6}{|l|}{ Terpenes } \\
\hline trans-Linalool oxide & 1076 & 3.3 & 0.5 & 0.8 & 0.9 \\
\hline a-Terpinolene & 1085 & 4.0 & 0.3 & 0.9 & 1.3 \\
\hline cis-Linalool oxide & 1091 & 1.7 & - & - & 0.4 \\
\hline Linalool & 1102 & 2.7 & - & - & 0.5 \\
\hline Menthol & 1179 & 2.4 & - & 1.4 & - \\
\hline Terpinen-4-ol & 1181 & 1.7 & 1.8 & 1.5 & 1.6 \\
\hline Linalyl propionate & 1193 & 12.3 & - & 3.0 & - \\
\hline Geranyl acetone & 1457 & 1.0 & - & 0.8 & 0.4 \\
\hline Total & & 29.1 & 2.6 & 8.4 & 5.1 \\
\hline \multicolumn{6}{|l|}{ Acids } \\
\hline Hexanoic acid & 980 & - & 0.6 & - & 0.8 \\
\hline 2-Ethylhexanoic acid & 1123 & 0.8 & - & 0.7 & 0.1 \\
\hline Octanoic acid & 1178 & - & 1.8 & 1.2 & 2.0 \\
\hline Nonanoic acid & 1278 & - & 0.6 & 3.2 & - \\
\hline Decanoic acid & 1375 & - & 5.5 & 2.7 & 8.7 \\
\hline Dodecanoic acid & 1569 & - & 4.0 & - & 4.4 \\
\hline Hexadecanoic acid & 1966 & - & - & - & 1.2 \\
\hline Total & & 0.8 & 12.5 & 7.8 & 17.2 \\
\hline \multicolumn{6}{|l|}{ Others } \\
\hline 1-Methoxy-4-methylbenzene ( $p$-methylanisole) & 937 & 0.7 & - & - & - \\
\hline 2-Phenylethanol & 1116 & - & - & - & 1.5 \\
\hline Methyl chavicol (estragole) & 1199 & - & 1.6 & 0.5 & 1.9 \\
\hline 4-Vinylphenol & 1225 & - & 6.1 & - & 7.3 \\
\hline Chavicol & 1260 & - & 0.4 & 2.8 & - \\
\hline Eugenol & 1361 & - & - & 1.3 & - \\
\hline 4-Methyl-2,6-bis(1,1-dimethylethyl)- phenol & 1476 & - & - & - & 0.7 \\
\hline Total & & 0.7 & 8.1 & 4.6 & 11.4 \\
\hline
\end{tabular}

RI-retention indices on HP-5MS column. ${ }^{\star}$ - compound tentatively identified. ${ }^{\text {a }}$ GS $=$ Granny Smith cultivar. ${ }^{\text {b }}$ ) GD $=$ Golden Delicious. ${ }^{\mathrm{c}}$ ) HGS $=$ hot enzyme treatment of Granny Smith cultivar. ${ }^{d}$ ) CGS = cold enzyme treatment of Granny Smith cultivar. ${ }^{e}$ ) HGD $=$ hot enzyme treatment of Golden Delicious. ${ }^{\mathrm{f}}$ ) CGD = cold enzyme treatment of Golden Delicious.

more specific for the hot enzyme treatments. In scope of hot treatment two apple cultivars are differentiated in relation to the content of methyl dihydrojasmonate which is more specific compound for the Golden Delicious while Granny Smith is determinate with 1-(1,1-dimethylethyl)-2-methyl1,3-propanediyl2-methylpropanoate and ethyl butanoate. Some differences among cultivars are results of differences in the degree of ethyl ester enhancement. These may be because of differential activity or synthesis of alcohol acyl CoA transferase (AAT) or alcohol dehydrogenase (ADH), separate iso-forms of AAT and ADH each with their own substrate specificity and then variation in alcohol precursors in different cultivars, or their combinations (Dixon \& Hewett, 2000).

Although esters are the main flavour contributors they do not confer a distinct apple flavour by itself. This requires a 
range of other compounds, such as alcohols, acids, aldehydes. Aliphatic alcohols presented the most abundant group of aromatic compounds in all apple juice samples (Table 2). In order to find the relationship between apple juice and aliphatic alcohol distributions PCA was applied. Inspection of Figure 3 shows better samples differentiation in relation to apple variety. Juice made from Golden Delicious apple cultivar is more specified

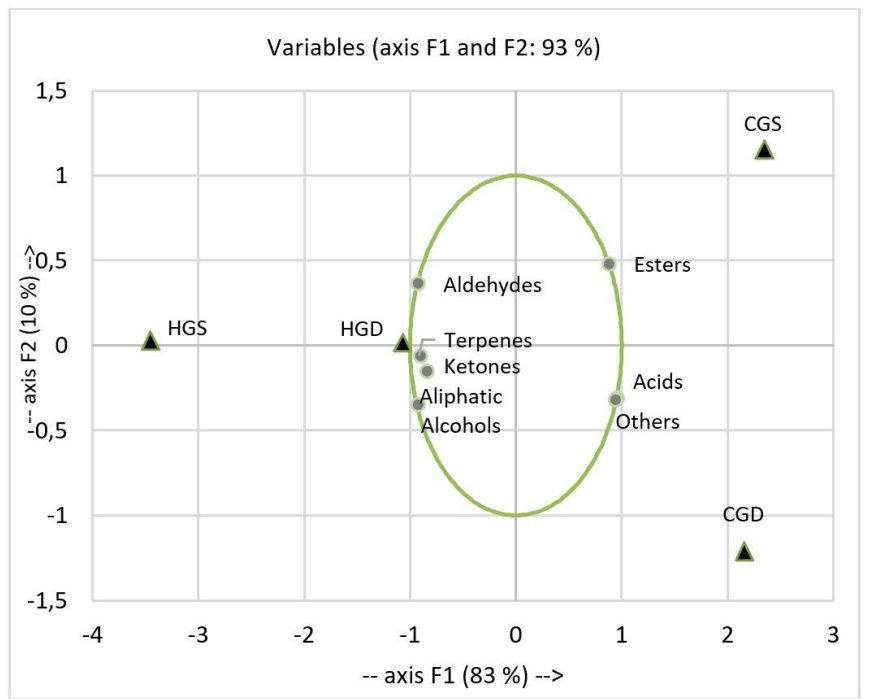

Figure 1. PCA biplot of the PCA performed on the total amount of chemical group and juice samples obtained by applying the two enzyme treatments on two apple cultivars (HGS-hot enzyme treatments of Granny Smith, CGS-cold enzyme treatments of Granny Smith; HGD- hot enzyme treatments of Golden Delicious, CGD - cold enzyme treatments of Golden Delicious.) with Octane-1,3-diol, 3-(methylthio)-propan-1-ol, Octan-1-ol, Decan-1-ol, Dodecan-1-ol, Heptan-1-ol aliphatic alcohols then juices made from Granny Smith cultivar.

Butan-1-ol is present in the same content in both apple cultivars but it is more specified for cold treatment. Juices made from Granny Smith are slightly separated from juice made of Golden Delicious on the basis of Hexan-1-ol, (Z)-Dec-3-en-1-ol, 2-Methylbutan-1-ol (Isoamyl alcohol), Octan-3-ol, 6-Methylhept-5-en-2-ol. Distribution of juice samples made from Granny Smith is determined by sum of peak area of aliphatic alcohols, shows also segregation in accordance with applied enzyme treatments. Hot enzyme treatment for Granny Smith is completely determinate with 2-Methylbutan-1-ol (Isoamyl alcohol), Octan-3-ol, 6-Methylhept-5-en-2-ol. Among the many alcohols detected in HGS treatment, these three aliphatic alcohols are represented with $63.46 \%$ of total alcoholic area (Table 2). Opposite, the cold enzyme treatment in juice produced by Granny Smith apple cultivar is slightly determinate with Hexan-1-ol (25.1\% peak area) and (Z)-Dec-3-en-1-ol. Apple juices are mainly characterised by flavour compounds responsible for fruity, ripe, and sweet aroma impressions, such as 1-butanol, 2-methyl-1-butanol, ethyl butyrate, and ethyl-2-methylbutyrate (Mehinagic et al., 2004). Considering obtained results, Granny Smith (hot enzyme treatment) is the alcohol type in accordance with Drawert's classification while Granny Smith (cold enzyme treatment) is the ester type as well Golden Delicious cultivar according to Paillard, 1990. As in the conducted study the predominant compounds in cold treatment were esters this is similar with previous work (López et al., 1998). Dirinck \&
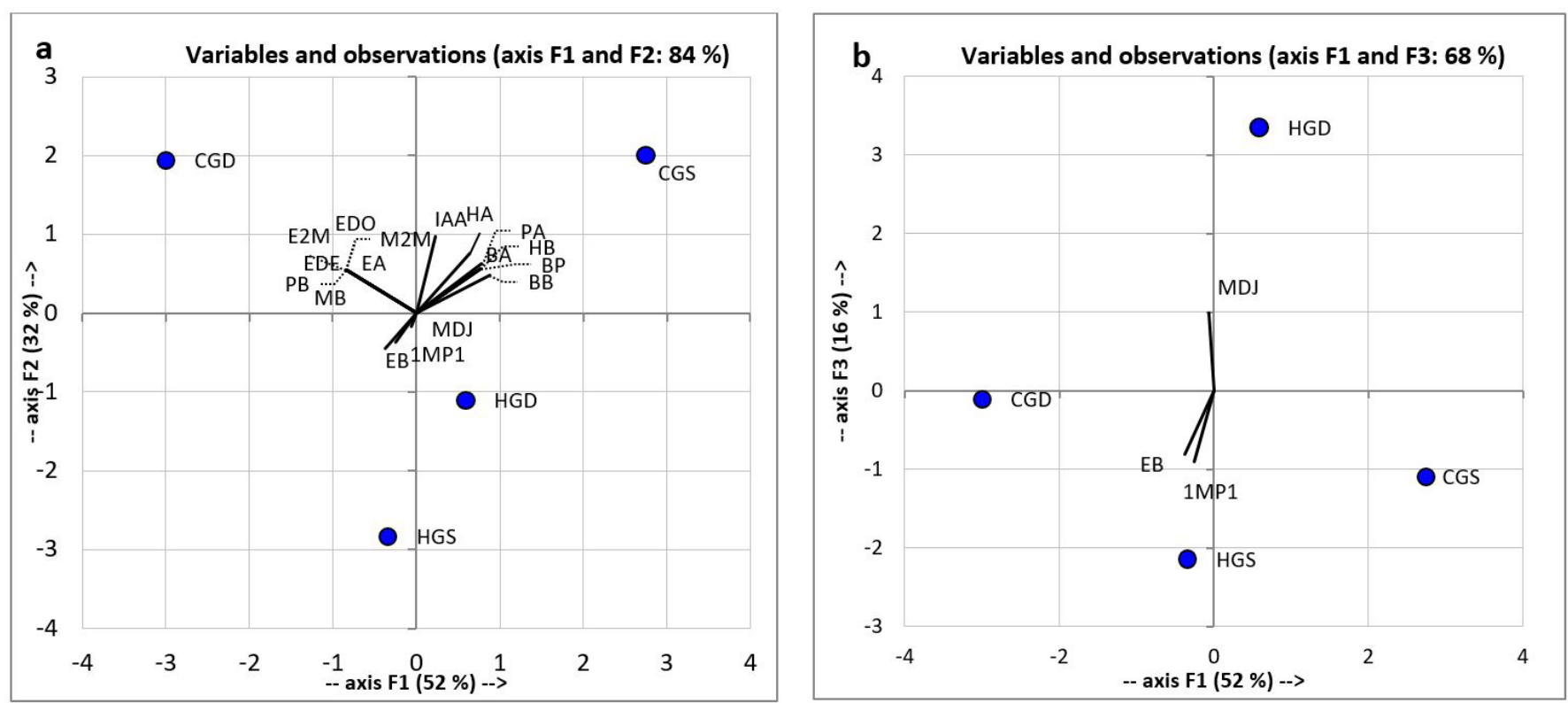

Figure 2. PCA biplot of the amount of esters in different juice samples on (a) PC1 versus PC2 and (b) PC1 versus PC3. Individual esters are distributed in relation to the sum of peak area of esters. HGS- hot enzyme treatments of Granny Smith, CGS-cold enzyme treatments of Granny Smith; HGD- hot enzyme treatments of Golden Delicious, CGD - cold enzyme treatments of Golden Delicious. EA-ethyl acetate, MB-methyl butanoate, M-2-M-methyl 2-methylbutanoate, EB-ethyl butanoate, BA-butyl acetate, E-2-M-ethyl 2-methylbutanoate, IAA-2-Methylbutyl acetate (isoamyl acetate), PB-propyl butanoate, BP-butyl propanoate, PA-pentyl acetate, BB-butyl butanoate, HA-hexyl acetate, HB-hexyl butanoate, EDE-ethyl decanoate, EDO-ethyl dodecanoate, 1-MP-1-(1,1-dimethylethyl)-2-methyl-1,3-propanediyl 2-methylpropanoate, MDJ-methyl dihydrojasmonate 
Schamp (1989) found that Granny Smith cultivar has high concentration of ethyl butanoate and hexan-1-ol these results in relation to hexane-l-ol are in agreement with the obtained ones above reported.

Many authors are worked on developing sensory profile of apple juice (Okayasuand \& Naito, 2001; Heil \& Ara, 2008; Wolter et al., 2010; Šimunek et al., 2013; Lilishentseva \& Smolyar, 2019; Mendes da Silva et al., 2019). All of them agree that it is important to incorporate essential sensory characteristic with cultivar or manner of juice production. In this work the five main sensory attributes were evaluated: taste, flavour, freshness, persistence and aftertaste. The results are present as average access of 24 semi trained assessors (Table 3). Statistical analysis showed that the cultivar is a statistically significant factor for the sensory quality of apple juice, while neither enzyme treatment (hot or cold) nor interaction between tested factors reported any statistically significant effect on the sensory attributes (Table 3). As Cheetham (2010) states much more basic flavour characteristics are variety dependent, as with acid apple varieties (Cox) as compared to sweeter varieties of lower acidity (Jonagold).

That is consistent with these sensory results, where are the all sensory attributes of juice samples made from Granny Smith cultivar evaluated as better. Sample produced by cold enzyme treatment get unsignificant higher sensory scores as compared to hot enzyme treatment (HGS total sensory scores 17.51 and CGS-18.17). These scores may be due to the fact that cold enzyme treatment is classified with higher amount of total esters than hot one (Table 2). These amount of ester obviously was not enough for sensory significant difference between samples. Authors Lo Scalzo et al. (2001) found that the apple juice, which was made from concentrate, consisted of mainly aroma compounds responsible for sensory evaluation impressions, such as 'fresh, green, citrus and shampoo-like' probably caused by technological processes, such as evaporation and pasteurisation, which gave rise to these aroma compounds. Also, it is clear that Granny
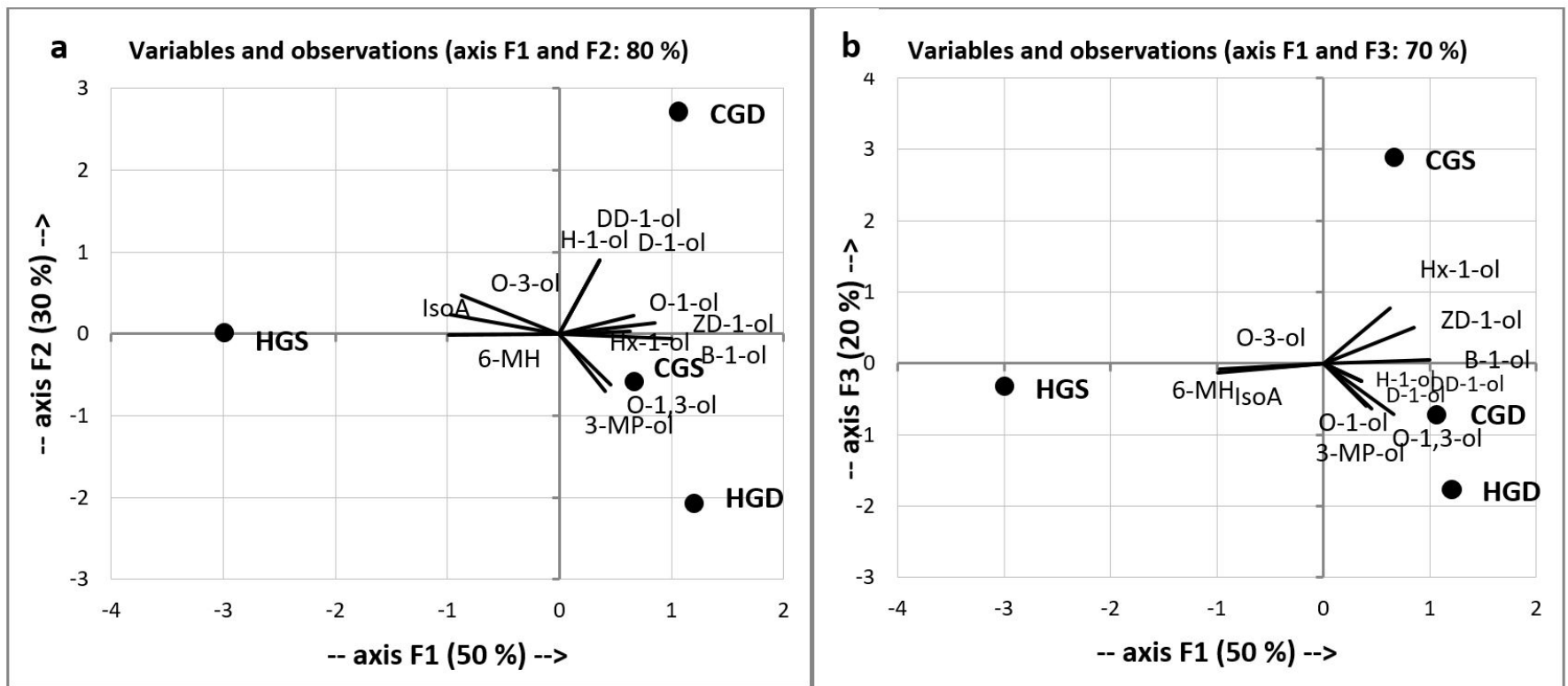

Figure 3. PCA biplot of the amount of aliphatic alcohols in different juice samples on (a) PC1 versus PC2 and (b) PC1 versus PC3. Individual aliphatic alcohols are distributed in relation to the sum of peak area of alcohols. HGS-hot enzyme treatments of Granny Smith, CGS-cold enzyme treatments of Granny Smith; HGD- hot enzyme treatments of Golden Delicious, CGD - cold enzyme treatments of Golden Delicious. B-1-ol-butan-1-ol, IsoA- 2-Methylbutan-1-ol (Isoamyl alcohol), Hx-1-ol-Hexan-1-ol, H-1-ol-Heptan-1-ol, 3-MP-ol-3-(methylthio)-propan-1-ol 6-MH-6-Methylhept5-en-2-ol,O-3-ol-Octan-3-ol, O-1-ol-Octan-1-ol, ZD-1-ol-(Z)-Dec-3-en-1-ol, O-1,3-ol-Octane-1,3-diol, D-1-ol-Decan-1-ol, DD-1-ol-Dodecan-1-ol.

Table 3. Sensory profile of clear apple juice.

\begin{tabular}{|c|c|c|c|c|c|c|c|c|c|}
\hline \multirow{2}{*}{ Sensory attributes } & \multicolumn{9}{|c|}{ Samples } \\
\hline & $\mathrm{HGS}^{\mathrm{a})}$ & $\mathrm{HGD}^{\mathrm{b})}$ & $\mathrm{C}$ & $\mathrm{CGS}^{\mathrm{c})}$ & $\mathrm{CGD}^{\mathrm{d})}$ & $\mathrm{C}$ & $\mathrm{C}$ & $\mathrm{T}$ & $\mathrm{CxT}$ \\
\hline Taste & $3.54 \pm 0.88$ & $2.96 \pm 0.86$ & $\mathrm{x}$ & $3.74 \pm 0.66$ & $3.17 \pm 0.65$ & $\mathrm{y}$ & * & ns & ns \\
\hline Freshness & $3.44 \pm 0.90$ & $2.86 \pm 0.85$ & $\mathrm{x}$ & $3.57 \pm 0.79$ & $3.08 \pm 0.78$ & $\mathrm{y}$ & * & ns & ns \\
\hline Persistence & $3.53 \pm 0.95$ & $3.10 \pm 0.82$ & $\mathrm{x}$ & $3.60 \pm 0.66$ & $3.24 \pm 0.77$ & $\mathrm{y}$ & * & ns & ns \\
\hline
\end{tabular}

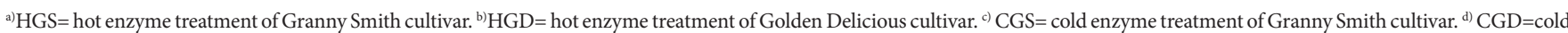
enzyme treatment of Golden Delicious. Different letters in rows from $\mathrm{x}$ to $\mathrm{y}$ for each sensory attributes indicate significantly different values among cultivars at $\mathrm{p}<0.05$. C - cultivar; $\mathrm{T}$ - enzymatic treatment $\mathrm{CxT}=$ interaction between cultivar and enzymatic treatment. ns- not significant; ${ }^{\star}$ - significant differences p-value below 0.05 ; 
Smith cultivar is sensory-wise more acceptable for juice than Golden Delicious. The reason is probably that the juice made of Granny Smith had a more sour taste (acidity $3.69 \mathrm{~g} / \mathrm{kg}$ - Table1), which the evaluators appreciated more for this type of product, as compared to Golden Delicious, which was less sour $(0.89 \mathrm{~g} / \mathrm{kg})$ (Table 1). The acidity is a very important precondition for taste and flavour of apple (Harker et al., 2002). According to Akagić et al. (2019), all analysed apple cultivars had sugar/acid rations lower than 20, being classified as sour-sweet or sour cultivars and appropriate processing and cider production. Also, the balance between sugars and organic acids is very important in achieving a harmonized taste for juice (Begić-Akagić et al., 2014). Consumers generally believe that more sour apple cultivars are better for juice production (Hudina \& Stampar, 2000). Wu et al. (2007) reported that Granny Smith cultivar is ideal for juice because it contains a significant amount of dry matter and sufficient acidity. The evaluators assigned the lowest average scores to the property of freshness of fruit juices in all tested variants (from 2.86 to 3.57). Average ratings for flavour and aroma were very close in all tested variants. This was expected because the aroma is closely tied to the product's taste. A similar situation happened with the average ratings that the panellist assigned to persistence and after taste of juice aroma because these two sensory parameters are conditioned by one another.

\section{Conclusion}

Finally, we highlight the importance for the juice industry to apply cold depectinization processes rather than hot ones during clear juice processing because this treatment better protects aroma compounds. The results of the sensory analysis confirmed the data of the analysis of aroma compounds of apple juice. Generally, clear apple juices produced of Granny Smith cultivar are preferred due to their characteristic "apple" and sweet-fruity flavour.

\section{References}

Akagić, A., Vranac, A., Gaši, F., Drkenda, P., Spaho, N., Oručević Žuljević, S., Kurtović, M., Musić, O., Murtić, S., \& Hudina, M. (2019). Sugars, acids and polyphenols profile of commercial and traditional apple cultivars for processing. Acta Agriculturae Slovenica, 113(2), 239251. http://dx.doi.org/10.14720/aas.2019.113.2.5.

Altisent, R., Graell, J., Lara, I., Lopez, L., \& Echeverria, G. (2011). Comparison of the volatile profile and sensory analyses of 'Golden Reinders" apples after the application of a cold air period after ultralow (ULO) storage. Journal of Agricultural and Food Chemistry, 59(11), 6193-6201. http://dx.doi.org/10.1021/ jf2005029. PMid:21528917.

Argenta, L. C., Mattheis, J. P., Fan, X., \& Finger, F. L. (2004). Production of volatile compounds by Fuji apples following exposure to high $\mathrm{CO}_{2}$ or low $\mathrm{O}_{2}$. Journal of Agricultural and Food Chemistry, 52(19), 5957-5963. http://dx.doi.org/10.1021/ jf049495s. PMid:15366849.

Azhu Valappil, Z., Fan, X., Zhang, H. Q., \& Rouseff, R. L. (2009). Impact of thermal and nonthermal processing technologies on unfermented apple cider aroma vilatiles. Journal of Agricultural and Food Chemistry, 57(3), 924-929. http://dx.doi.org/10.1021/jf803142d. PMid:19154152.

Beaulieu, J. C., \& Baldwin, E. A. (2002). Flavour and Aroma of freshcut fruits and vegetables. In O. Lamikanra (Ed.), Fresh-cut fruits and vegetables (pp. 397-431). Washington, DC: CRC Press. http:// dx.doi.org/10.1201/9781420031874.ch12.

Begić-Akagić, A., Spaho, N., Gaši, F., Drkenda, P., Vranac, A., Meland, M., \& Salkić, B. (2014). Sugar and organic acid profiles of the traditional and international apple cultivars for processing. Journal of Hygienic Engineering and Design, 7, 190-196.

Begić-Akagić, A., Spaho, N., Oručević, S., Drkenda, P., Kurtović, M., Gaši, F., Kopjar, M., \& Piližota, V. (2011). Influence of cultivar, storage time, and processing on the phenol content of cloudy apple juice. Croatian Journal of Food Science and Technology, 3(2), 1-8.

Brotlija, M., Karalija, L., Rovčanin, A., Begić-Akagić, A., \& Drkenda, P. (2010, September-October 29-2). Effect of physical properties of row material and depectinization and sensory features of apple juice. In Proceedings of the 21st Scientific-Expert Conference of Agriculture and Food Industry (pp. 739-746), Neum, Bosnia and Herzegovina: Faculty of Agriculture and Food Sciences, University of Sarajevo.

Carbone, K., Giannini, B., Picchi, V., Lo Scalzo, R., \& Cecchini, F. (2011). Phenolic composition and free radical scavenging activity of different apple varieties in relation to the cultivar, tissue type and storage. Food Chemistry, 127(2), 493-500. http://dx.doi.org/10.1016/j. foodchem.2011.01.030. PMid:23140692.

Cheetham, P. S. J. (2010). Natural sources of flavours. In A. J. Taylor \& S. T. R. Linforth (Eds.), Food flavour technology (pp. 143-193). Oxford: Blackwell Publishing Ltd. http://dx.doi. org/10.1002/9781444317770.ch5.

Dirinck, P., \& Schamp, N. (1989). Instrumental aroma analysis for objective evaluation of the parameters influencing aroma formation in apples and for prediction of the optimum picking date. Acta Horticulturae, (258), 421-428. http://dx.doi.org/10.17660/ ActaHortic.1989.258.48.

Dixon, J., \& Hewett, E. W. (2000). Factors affecting apple aroma/flavour volatile concentration: A Review. New Zealand Journal of Crop and Horticultural Science, 28(3), 155-173. http://dx.doi.org/10.1080/01 140671.2000.9514136.

Espino-Díaz, M., Sepúlveda, D. R., González-Aguilar, G., \& Olivas, G. I. (2016). Biochemistry of apple aroma: A review. Food Technology and Biotechnology, 54(4), 375-397. http://dx.doi.org/10.17113/ ftb.54.04.16.4248. PMid:28115895.

Fellman, J. K., \& Mattheis, J. P. (1995). Ester biosynthesis in relation to harvest maturity and controlled-atmosphere storage of apples. In R.L. Rouseff \& M.M. Leahy (Eds.), Fruit flavours: Biogenesis, characterization, and authentication (p. 149). Washington, D.C.: American Chemical Society. http://dx.doi.org/10.1021/bk-19950596.ch014.

Ferreira, L., Perestrelo, R., Caldeira, M., \& Câmara, J. S. (2009). Characterization of volatile substances in apples from Rosaceae family by headspace solid-phase microextraction followed by GCqMS. Journal of Separation Science, 32(11), 1875-1888. http://dx.doi. org/10.1002/jssc.200900024. PMid:19425016.

Fraternale, D., Ricci, D., Flamini, G., \& Giomaro, G. (2011). Volatiles profile of red apple from Marche Region (Italy). Records of Natural Products, 5, 202-207.

Gasperi, F., Aprea, E., Biasioli, F., Carlin, S., Endrizzi, I., Pirretti, G., \& Spilimbergo, S. (2009). Effects of supercritical CO(2) and $\mathrm{N}(2) \mathrm{O}$ pasteurisation on the quality of fresh apple juice. Food Chemistry, 115(1), 129-136. http://dx.doi.org/10.1016/j. foodchem.2008.11.078.

Gonçalves, B., Oliveira, I., Bacelar, E., Morais, M. C., Aires, A., Cosme, F., Ventura-Cardoso, J., Anjos, R., \& Pinto, T. (2018). Aromas and Flavours of Fruits. In A. Vilela (Ed.), Generation of aromas 
and flavours. London: Intech Open. Retrieved from https://www. intechopen.com/books/generation-of-aromas-and-flavours/aromasand-flavours-of-fruits

Harker, F. R., Marsh, K. B., Young, H., Murray, S. H., Gunson, F. A., \& Walker, S. B. (2002). Sensory interpretation of instrumental measurements2: sweet and acid taste of apple fruit. Postharvest Biology and Technology, 24(3), 241-250. http://dx.doi.org/10.1016/ S0925-5214(01)00157-0.

Heil, M., \& Ara, V. (2008). Aroma of fruit juices II - Composition and valuation of apple juice aroma. Fruit Processing, 18(3), 126-134.

Hey, M., Kürbel, P., Hopf, I., \& Dietrich, H. (2007). Untersuchung sortenreiner Apfelsaftaromen. Flüssiges Obst, 78(2), 62-67.

Hey, M., Patz, C. D., \& Will, F. (2008). Geisenheimer Standpunkt zur Aromadiskussion. Flüssiges Obst, 75(1), 32-33.

Holland, D., Larkov, O., Yaaacov, I. B., Bar, E., Zax, A., Brandeis, E., Ravid, U., \& Lewinsohn, E. (2005). Developmental and varietal differences in volatile ester formation and acetyl-CoA: alcohol acetyl transferase activities in apple fruit. Journal of Agricultural and Food Chemistry, 53, 7198-7203. http://dx.doi.org/10.1021/ jf050519k. PMid:16131130.

Hudina, M., \& Stampar, F. (2000). Sugars and organic acids contents of European (Pyrus communis L.) and Asian (Pyrus serotina rehd.) pear cultivars. Acta Alimentaria, 29(3), 217-230. http://dx.doi. org/10.1556/AAlim.29.2000.3.2.

Iaccarino, N., Varming, C., Agerlin Petersen, M., Viereck, N., Schütz, B., Toldam-Andersen, T. B., Randazzo, A., \& Balling Engelsen, S. B. (2019). Ancient Danish Apple Cultivars-A Comprehensive Metabolite and Sensory Profiling of Apple Juices. Metabolites, 9(7), 139-156. http://dx.doi.org/10.3390/metabo9070139. PMid:31373318.

Kevers, C., Pincemail, J., Tabart, J., Defraigne, J. O., \& Dommes, J. (2011). Influence of cultivar, harvest time, storage conditions, and peeling on the antioxidant capacity and phenolic and ascorbic acid contents of apples and pears. Journal of Agricultural and Food Chemistry, 59(11), 6165-6171. http://dx.doi.org/10.1021/ jf201013k. PMid:21548601.

Komthong, P., Igura, N., \& Shimoda, M. (2007). Effect of ascorbic acid on the odours of cloudy apple juice. Food Chemistry, 100(4), 13421349. http://dx.doi.org/10.1016/j.foodchem.2005.10.070.

Lea, A. G. H. (1999). Apple juice. In P. R. Ashurst (Ed.), Production and packaging of non-carbonated fruit juices and fruit beverages (pp. 153-196). Boston, MA: Springer. http://dx.doi.org/10.1007/978-14757-6296-9_6.

Liaudanskas, M., Viskelis, P., Jakštas, V., Raudonis, R., Kviklys, D., Milašius, A., \& Janulis, V. (2014). Application of an optimized HPLC method for the detection of various phenolic compounds in apples from lithuanian cultivars. Journal of Chemistry. 2014, 1-10. http:// dx.doi.org/10.1155/2014/542121.

Lilishentseva, A., \& Smolyar, A. (2019). Descriptor-profile for determining the quality of apple juice samples. Food Science and Technology, 13(4), 118-126.

Lo Scalzo, R., Testoni, A., \& Genna, A. (2001). Annurca apple fruit, a southern Italy apple cultivar: textural properties and aroma composition. Food Chemistry, 73(3), 333-343. http://dx.doi. org/10.1016/S0308-8146(00)00306-X.

López, M. L., Lavilla, M. T., Riba, M., \& Vendrell, M. (1998). Comparison of volatile compounds in two seasons in apple: 'Golden Delicious' and 'Granny Smith'. Journal of Food Quality, 21(2), 155-166. http:// dx.doi.org/10.1111/j.1745-4557.1998.tb00512.x.
Mehinagic, E., Prost, C., \& Demaimay, M. (2004). Optimization of extraction of apple aroma by dynamic headspace and influence of saliva on extraction of volatiles. Journal of Agricultural and Food Chemistry, 52(16), 5175-5182. http://dx.doi.org/10.1021/jf049577g. PMid:15291493.

Mehrabani, L. V., Dadpour, M. R., Delazar, A., Movafeghi, A., \& Hassanpouraghdam, M. B. (2011). Quantification of Phenolic Compounds in Peel and Pulp of 'Zonouz' Apple Cultivar from Iran. Romanian Biotechnological Letters, 16(4), 6387-6393.

Mendes da Silva, T., Marinoni, D. T., Peano, C., \& Giuggioli, N. R. (2019). A new sensory approach combined with a TextMining Tool to Create a Sensory Lexicon and Profile of Monovarietal Apple Juices. Foods, 8(12), 608. http://dx.doi.org/10.3390/foods8120608. PMid:31766769.

Nikfardjam, M. P., \& Maier, D. (2011). Development of a headspace trap HRGC/MS method for the assessment of the relevance of certain aroma compounds on the sensorial characteristics of commercial apple juice. Food Chemistry, 126(4), 1926-1933. http://dx.doi. org/10.1016/j.foodchem.2010.12.021. PMid:25213978.

Okayasuand, H., \& Naito, S. (2001). Sensory characteristics of apple juice evaluated by consumer and trained panels. Journal of Food Science, 66(7), 1025-1029. http://dx.doi.org/10.1111/j.1365-2621.2001.tb08229.x.

Paillard, N. M. M. (1990). The flavour of apples, pears and quinces. In I.D. Morton \& A.J. Macleod (Eds.), Food Flavours (pp. 1-41). Amsterdam: Elsevier Science Publishing Company.

Perez-Cacho, P. R., Galan-Soldevilla, H., Mahattanatawee, K., Elston, A., \& Rousef, R. L. (2008). Sensory lexicon for fresh squeezed and processed orange juices. Food Science \& Technology International, 14(5), 131-141. http://dx.doi.org/10.1177/1082013208094723.

Quadt, A., Julish, E., \& Tretzel, J. (2008). Sensorische und analytische beurteilung von Apfelsaftaromen. Flüssiges Obst, 75(09), 448-457.

Riu-Aumatell, M., Castellari, M., Lopez-Tamames, E., Galassi, S., \& Buxaderas, S. (2004). Characterisation of volatile compounds of fruit juices and nectars by HS/SPME and GC/ MS. Food Chemistry, 87(4), 627-637. http://dx.doi.org/10.1016/j. foodchem.2003.12.033.

Roth, E., Berna, A. Z., Beullens, K., Yarramraju, S., Lammertyn, J., Schenk, A., \& Nicolai, B. M. (2007). Postharvest quality of integrated and organically produced apple fruit. Postharvest Biology and Technology, 45(1), 11-19. http://dx.doi.org/10.1016/j. postharvbio.2007.01.006.

Rowan, D. D., Allen, J. M., Fielder, S., \& Hunt, M. B. (1999). Biosynthesis of straight-chain ester volatiles in red delicious and granny smith apples using deuterium-labeled precursors. Journal of Agricultural and Food Chemistry, 47(7), 2553-2562. http://dx.doi.org/10.1021/ jf9809028. PMid:10552526.

Schmutzer, G. R., Magdas, A. D., David, L. I., \& Moldovan, Z. (2014). Determination of the volatile components of apple juice using solid phase microextraction and gas chromatography-mass spectrometry. Analytical Letters, 47(10), 1683-1696. http://dx.doi.org/10.1080/00 032719.2014 .886694 .

Sharma HP, Patel H, \& Sugandha (2015). Enzymatic extraction and clarification of juice from various fruits - A review. Critical Reviews in Food Science and Nutrition, 57(6), 1215-1227. http://dx.doi.org/ 10.1080/10408398.2014.977434. PMid:26731188.

Šimunek, M., Režek Jambrak, A., Petrović, M., Juretić, H., Major, N., Herceg, Z., Hruškar, M., \& Vukušić, T. (2013). Aroma profile and sensory properties of ultrasound-treated apple juice and nectar. Food Technology and Biotechnology, 51(1), 101-111. 
Steffen, A., \& Pawliszyn, J. (1996). Analysis of flavor volatiles using headspace solid-phase microextraction. Journal of Agricultural and Food Chemistry, 44(8), 2187-2193. http://dx.doi.org/10.1021/jf950727k.

Thielen, C., Ludwig, M., Patz, C. D., Will, F., Dietrich, H., Netzel, G., Netzel, M., Bitsch, R., \& Bitsch, I. (2006). Characterization of juices of different apple cultivars. Deutsche Lebensmittel-Rundschau, 102, 426-435.

Vikram, V. B., Ramesh, M. N., \& Prapulla, S. G. (2005). Thermal degradation kinetics of nutrients in orange juice heated by electromagnetic and conventional methods. Journal of Food Engineering, 69(1), 31-40. http://dx.doi.org/10.1016/j.jfoodeng.2004.07.013.

Weenen, H., \& van der Ven, J. G. M. (2001). The formation of strecker aldehydes. In G. R. Takeoka, M. Güntert \& K.-H. Engel. Aroma active compounds in foods (pp. 183-195). Washington: American Chemical Society. http://dx.doi.org/10.1021/bk-2001-0794.ch015
Wolter, C., Achim Gessler, A., \& Winterhalter, P. (2010). Evaluation of apple juice aroma. In N. Da Costa \& R. J. Cannon (Eds.), Flavors in noncarbonated beverages (pp. 103-114). Washington, DC: American Chemical Society. http://dx.doi.org/10.1021/ bk-2010-1036.ch008.

Wu, J., Gao, H., Zhao, L., Liao, X., Chen, F., Wang, Z., \& Hu, X. (2007). Chemical compositional characterization of some apple cultivars. Food Chemistry, 103(1), 88-93. http://dx.doi.org/10.1016/j. foodchem.2006.07.030.

Young, J. C., Chu, C. L. G., Lu, X., \& Zhu, H. (2004). Ester variability in apple varieties as determined by solid- phase microextraction and gas chromatography- mass spectrometry. Journal of Agricultural and Food Chemistry, 52(26), 8086-8093. http://dx.doi.org/10.1021/ jf049364r. PMid:15612800. 